\title{
Islamic Art and Language as a Source of Inspiration Leading to Traditional Arabic Calligraphy Art
}

\author{
Duaa Mohammed Alashari ${ }^{*}$, Abd.Rahman Hamzah, Nurazmallail Marni, \\ Faculty of Islamic Civilization, Universiti Teknologi Malaysia, 81310 Johor Babru, Malaysia \\ *Corresponding author:duaa1983@graduate.utm.my
}

\section{Article history}

Received: 2019-02-27 Received in revised form: 2019-07-07 Accepted: 2019-07-08 Published online: 2019-10-31

\begin{abstract}
The Islamic art has developed from different kind of visual art. Arabic calligraphy is one of the most prominent arts starting from the revolution of the Quran and has a long history. This paper will help to provide some sources of information that can be used by people who would like to understand and study the Islamic calligraphy and Islamic art. Also, this paper is connecting the Arabic language to universal spirituality and express how Arabic calligraphy has become a prominent feature in Islamic world. Indeed, this paper provides a brief of the long history of Islamic calligraphy, explains about some of various of Arabic fonts style, and some important Quranic colour that has significant in the Islamic culture. Arabic calligraphy, which is also known as Islamic calligraphy, has a long history of development starting from the first written form of the Quran, in the early $7^{\text {th }}$ century. The Arabic calligraphy art presents how to understand and appreciate its varied styles and modes. Calligraphers start creating their art by using some passages from the Quran or Arabic poems as a starting point then they develop their compositions in a complex and intricate piece of art by the overlap of Arabic letter and words that integrate. Arabic calligraphy is about movement, rhythm and dynamism as seen through the calligraphic marks in most mosques or Islamic building or Islamic calligraphy painting. Islamic calligraphy presents the aspect of aesthetic principles and demonstrate the love for Arabic language and culture with the aesthetic methods of traditional Arabic art.
\end{abstract}

Keywords: Islamic civilization, Arabic Calligraphy, Islamic Art, Arabic language, Quranic colour. 


\subsection{INTRODUCTION}

In Islamic civilization the art of Arabic calligraphy was venerated as a sacred trust form. Also, calligraphy is an art that preserves the actual word of God once written on paper for preserved for future generation. This art is considered sacred by Muslim for centuries. Calligraphy is type of script appear after the revolution of the Quran. The calligraphic call is not, admire the material world, but admire the Almighty God (Teparic, 2013). The meaning of Arabic calligraphy is a beautiful writing in Greek and it is considered one of the earliest forms for writing the Quran dating back to 7 centuries. Arabic calligraphy has a unique character that makes it special from other kinds of calligraphy art in the world.

In related study, Nasiruddin (2004) reveals that, "the art of calligraphy, as it is known presently, finds its origin in cave paintings. In the days when communication was a series of grunts, the written word was a mere pictorial representation of significant events in a caveman's life." Arabic language has a strong influenced to many Arabic and non-Arabic calligraphers and directed them to create amazing and beautiful traditional Arabic calligraphy art that present the aesthetic aspect of Islamic art. This kind of art reflects the long history and diversity of Muslim civilization.

Calligraphers through their work seek the sacred words of the Quran emerge together as a sacred level for spiritual meditation. Tunisian professor Rashida Triki writes, "The gaze is constantly deprived of its ability to read and is brought back to pure pictorial seeing." (Paul, 2009). The Arabic calligraphy evokes language as well as echo the classic tradition style and use Quranic colours that are famous in ancient Eastern societies. However, all tradition calligraphers produce their artwork on building upon the long history of Arabic calligraphy style as a source of inspiration. Tradition Arabic calligraphy art has power and expresses the beauty concept and the depth of heritage in the Arabic language. Also, it is presenting the complexity of different Arabic culture society. Inaddtion, traditional Islamic calligraphy art has a unique style that is presenting the complex composition of the unique perspective of Islamic art.

Also, the tradition Arabic artwork conveys the universality of spirituality in all cultures through the aesthetic dimension of language, According to Wijdan Ali, the art of abstraction in Islamic art was not born from any lack of skill on the artist part, but from his rejection of materialism and its ephemeral qualities. His quest was one for the eternal representation of the spirit (Wijdan, 1989). Islamic art means a unity of style and purpose (Barbara. 1991). Indeed, Islamic art focuses on Arabic calligraphy and Islamic patterns that comes from natural and geometric shapes as the source of inspiration. In addition, Islamic art presents the most important elements of design such as rhythm, balance, symmetry, pattern and unity.

Arabic calligraphy is beyond the recipe of shrouds of Islamic art because of its aesthetic, religious and spiritual values. The Arabic alphabet is one of the most beautiful characters in the world. It is distinguished by its unique beauty and uniqueness. It has a great cultural material. It has schools and professors in different times and places such as Kufic, and Thulth line. The Persian calligraphy, which originated in Persia, and the Diwani line, which was drawn by officials and successors of the Ottoman Empire. Arabic calligraphy was appeared at the hands of famous Turkish calligraphers. In addition to the multiplicity of schools, Calligrapher Ibn al-Maqla and Ibn al-Bawab and the Ottoman calligrapher Haddad Al-Amassi who reached the Arabic calligraphy to the top of what reached the line of Tawheed and especially the Thulth line.

The primacy of the word in Islam is reflected in the virtually universal application of calligraphy. Writing is given pride of place on all kinds of objects of everyday use as well as entire 
wall surfaces, mosque furniture, the interiors and exteriors of mosques, tombs, and al-Kaaba, the most famous sanctuary of Islam (Safadi, 1978).

\subsection{THE BRIEF HISTORY OF ISLAMIC CALLIGRAPHY}

Islamic calligraphy is one of the main aspects of Islamic art and consider the heart of art in Islamic civilization. When the revolution of Islam beginning in the $7^{\text {th }}$ C.E, the prophet Muhammad encourage people to read and write. David (1989) concurs that "the history of Arabic calligraphy began in the seventh century A.D in a script from that of the Nabataeans, a Hellenized Arabic-speaking people from west of River Jordan, the builders of Petra in Jordan and Median Salih in Saudi Arabia." The word calligraphy in Arabic means "handast al-khatt," which means the geometry way of writing the Arabic. The Arabic script that was developed from the Semitic alphabet which existed in the Arab Peninsula at the time Prophet Muhammad (peace be upon him) started preaching (Schimmel, 1970).

Prophet Muhammad enhanced the importance of writing to his followers as there were only few of them in the beginning who could read and write and had committed to the Quran writing, including the four early caliphs. Uthman, the third caliph, put the material into order which is still preserved today and Ali, the fourth caliph, contributed valuable touch in calligraphy as he was also considered by the later calligraphers, as the first master of calligraphy (Schimmel,1970). At the end of Prophet's life, he had about thirty thousand contemporaries who had heard and memorized the Quran in whole or in parts (Faruqi, Lois,1986).

The Arabic calligraphy is wisdom language because it conveys the Quran (the word of God). Calligraphers started using calligraphy to express concepts of spirituality in written the 'Quran." The Quran is the words of Allah revealed to the prophet Muhammad by the angel Gabriel. Islamic ban on creating the image of living beings comes from the traditions of the Prophet. Ban was intended to deter converts to the new religion from reverting to atheism and the worship of idols. Idols were worshipped by the most inhabitants of the Arabian Peninsula before the advent of Islam.

Arabic calligraphy began with the advent of Islam and existence of the Quran. Arabic language belongs to the family of the sematic language that existed before the light of Islam. The origin written Arabic can be traced to the northern Arabian Peninsula. By the late 6 centuries, the Arabic script arrived the Hejaz with the revolution of the Quran. The form of Arabic language became immortalized and the Arabic language provide a tremendous impact on the world history. After few centuries the Quran inspired most of civilization that been adopted Islam. Throughout Asia and other countries people became fluent in the Arabic language. Arabic became a universal international language. This led to increasing demand growing need for the reproduction of the Quran.

Figurative painting and the sculpture of living beings was, and is, banned in places of worship so that they would not distract worshippers from their prayers and spiritual meditation. (Wijdan, Bisharat, Barbican, 1989). In 622 C.E. the Islamic worldviews started and the calligraphy was developing some ways of writing to emphasize and retain to the verses of the Quran from losing or oblivious or omission. Arabic calligraphers were focusing on the most important aspect the aspect of aesthetic and perfection as well as focusing on the aspect of meaning of the verses. Calligraphers were Searching for some ways of balance to combine the aesthetic element of writing at the same time without losing meaning of the word to achieve meaning with spirituality. In the early Islamic era calligraphers were in a very high position in Muslim society. 
They were the only people who were copying the Quran and Muslim society express an appreciation to them. One of the famous calligraphers. The name of the classical calligraphers began to appear since the tenth century AD - Ibn Muqla, Ibn al-Bawwab, and others (Blair \& Bloom, 2017). The first development of Arabic calligraphy started with the first written version of the Quran by Zaid Ibn Thabit during the caliphate of Utham Ibn Affan 644 C.E. The early scripts of the Muslim era are represented on the monuments of the Umayyads (Wijdan,1989). There are many examples that are presents the Quranic inscription one of the earlier is the Dome of Rock in Jerusalem. The earliest cities for starting the Arabic calligraphy was Mecca, Medina, Kufah and Basrah.

The call of the learning of Arabic calligraphy began in the Umayyad era, after the succession of the Kufah moved to the Levant, which helped greatly in the development of the calligraphy and its tools. The calligraphers began to improve the writing and copy of the Qur'an. Ibn Al-Muqlah was one of the pioneers of the Arabic calligrapher and he was credited with turning the line from the kufic line to more flexible forms. The line of Altomar and the Galilee pen is a pole and from here the calligraphers began to devise and invent new additions styles that did not depart from the grammar of the calligraphy.

And in the Umayyad era spread the concern to write a beautiful handwriting and decoration the Koran and the Prophetic Hadith with the use of gold water. one of the well- known Umayyad calligraphers was Hassan Al-Basri, who was born and died in Basra in $115 \mathrm{AH}$. He was writing the Koran and knew for the improvement of the Arabic calligraphy. The minister Ibn Makla took the first carrier of the line, but the first carrier of the Arabic calligraphy is Hassan al-Basri, who in turn took Ali ibn Abi Talib (Ibn Khalkan, 1943). The Arabic calligraphy in the Umayyad period created great distances from development and reached the Abbasid period.

In the Abbasid era, Baghdad was founded by Abu Jaafar al-Mansur and became a center of Arab civilization and calligraphy. The calligraphers of the Arabic calligraphy were developing a new style of writing. Many calligraphers emerged, and the line flourished with decoration, coloring, gilding and flair. Dahak bin Ajlan and Ishaq bin Hammad were famous at the beginning. In the era of the Caliph al-Mamun, many calligraphers appeared in the same manner as their predecessors, including Ibrahim al-Shajari, who developed the Holy Quran into the pen of the two-thirds.

In the Abbasid era, Arabic calligraphy and calligraphers became a place of great importance and status. The calligrapher function became one of the most important functions at the level of the state. The calligraphers invented writing on the walls of Islamic architectural monuments such as mosques and palaces and adding decorative art to the architectural features for meditation and reflection on beauty and rhythm. Arabic letters and became a linear composition in the Abbasid period do not depend on reading, but beyond which the spiritual side and emotional.

In the Abbasid era, the Arabic alphabet became a major element in the decoration. The Arabic fonts became adorned the domes, mosques, mansions and palaces. The minister Ibn Makla appeared, who set the line and set his measurements and rules and golden virtues. In deed, he gave the line smooth and movement. Then came the son of the calligrapher Yaiqot Almstasmi who made excelled in the quality of the calligraphy and set up the rules and the pens for most Arabic calligraphy style. The Abbasid era was one of the golden ages for flourish Arabic calligraphy types and tools.

Most research of the Islamic calligraphy was about the history of the calligrapher special Ibn Muqla, Ibn al-Bawwab, and Yaqut al-Mustasimi. "These calligraphers are generally thought by most historians of the subject to be pivotal figures in a direct chain of transmission whose ultimate 
source was the prophet Muhammad" (Fu, Lowry, Yonemura,1986).

Since the expansion of the Islamic empire, the Arabic language take over the languages used in the Middle East such as Persian and Syriac. Islamic civilization expanded and started to spread to many countries in Africa and Asia. Learning the Arabic language was very important for Asians and Africans people to let them know more about Islam and they used it for communicating and spreading knowledge. The Arabic alphabet belongs to a group of Semitic scripts that developed from the Nabataeans script, which was itself derived from the Aramaic script. Major developments occurred in the writing system of Arabic including the development of different styles (Fayeq, 2002).

Zakariya (2002) states that, "one cannot precisely ascertain or described how the early writing looks like, but the earliest written forms can only be guessed. Inscriptions on stone suggested both unconnected and connected letter alphabets were in use. The connected letter alphabet is recognizable as the true Arabic alphabet". Zakariya continues that "it was on record and established that fewer people in the Prophet Muhammad's (P.B.U.H) lifetime knew how to read and write. He also had scribes, to write for him, as he was unlettered."

One of the most famous written the Quran is known as Kufic script. This kind of style is extremely versatile. In deed, its name took from the Kufa city in Iraq. Kufa city at that time was the center of enlightenment and learning for Arabic language. Kufic script developed by its letters which were angular and gemetrical. The kufic style considerd as the basic of most present Arabic scripts. As the years pass the Arabic calligraphy evolved many calligraphic styles.

\subsection{THE FAMOUS STYLES AND TOOLS OF ISLAMIC CALLIGRAPHY}

As Arabic calligraphy developed throughout the time more cursive scripts became wellknown. These scripts referred to the six pen or "Alaqlam Alsetab" for calligraphy. In addition, all these styles are subject to strict calligraphic rules. The famous styles of written calligraphy are Kufi, Thuluth, Naskh, Farsi, Deewani, and Riqa'a and these are considered the most familiar styles. According to Oweis Fayeq, The Kufic style is noted for its proportional measurements, angularity and squareness and as one of the earliest styles to be used to record the Quran. The other five styles are noted for their cursive letters and their use as ornamental scripts (Fayeq, 2002).

Additionally, there is Tughra style was famous used by the Ottoman Sultans as their signature. The calligraphic call is not, admire the material world, but admire the Almighty God" (Teparic, 2013). One of the oldest styles of writing Arabic is called the Kufic because it started on the city of the Kufah in Iraq on the $7^{\text {th }}$ century. This kind of written known as angular or rectangular style, after the kufic style calligraphers developed more curvilinear styles which are named individually based on the places that comes from. The earlier version of copying the Quran from the eighth century is in a kufic style. Nasiruddin (2004) continues his statement and adds that "the first copies of the Quran were written in Kufic style. This style of writing is a form of script consisting of straight lines and angles. The script has specific proportional measurements, along with pronounced angularity and squareness. Under Umayyads and Abbasids era curvilinear style were developed for secular function.

The naskhi style started at the ninth century, invented by Ibn Muqlah calligrapher. According to Najda "Naskhi, the rounded script, remained in use and from it most of the many later styles of Arabic calligraphy have been developed" (Najda, 1994). The naskhi is a cursive script with elongate letters that much used by government and academic scholers. This new script devolped 
in each different region. Accordingly, calligrapher gradually adopted the naskhi style. The ancient calligrapher used his talent to introduce to the readers new Arabic kind variation is Ibn Muglah. Zakariya (2002) reveals that "one of the leading calligraphers at the inception of this artistic expression is Abu Ali Muhammad ibn Ali. He is popularly known and addressed as Ibn Muglah. Ibn Muglah was born in 886A.D in Bagdad, present day Iraqand died in 940 A.D.” His contribution for Arabic calligraphy was up of most important through his time. Ibn Muglah regulated script according to geometrical principles and establishing a unit of measure for each letter with creating a balance. The term on naskhi in Arabic language means copy. This style of script derived from the thuluth form. It was called Naskh because scribes used it in transcribing the Qurans (Khader, 2001). The naskhi can be described as a scribal hand and most of the lines are curved. This style was famous for written the Quran because it is easy to read the word also, the naskhi form was using for printing. Siddiqua (2011) admits that, "Naskh is relatively easy to read and write, this is because it was a frequently used script for writing Qur" an after it was redesigned in the tenth century A.D by Ibn Muglah. It was derived from Thuluth, by introducing a number of modifications resulting in smaller size and greater delicacy."

In Saliu (2013) writes that, "the primacy of the word in Islam is reflected in the virtually universal application of Arabic calligraphy. Writing is given pride of place on all kinds of objects: of everyday use as well as entire wall surfaces, mosque furniture, the interiors and exteriors of mosques, tombs and Kabah. Like the icons of most other faiths, script also represents power. Its preeminent use is the writing of divine message of the Quran.” (Saliu, 2013).

Over time the Arabic calligraphy has been the main type of art that is decorating most of the mosques in Muslim world. According to Mohamed Zakariya, we can trace the first evolution of writing into an esthetically mature calligraphy to this period. The grand inscription belt in the Dome of the Rock is the lasting testimony of those first century concepts something totally new in world art. Executed in mosaic tiles, this band of calligraphy is a perfectly legible, fully artistically realized monumental form of the earliest Koranic script. To be that good, that confident and exuberant only seven decades after the Hijra, is impressive. The concept of the belt in calligraphy as an architectural component is still used today in fresh ways (Barbara, 1991).

A large cursive script generally used for monumental inscription known as thuluth. The style of the thuluth script one of the most famous style that invented by Ibn Muqlah an Iraqi calligrapher. The Tenth line is a type of Arabic font, first appeared in the fourth century AH. It is one of the most famous types of lines that are derived from the calligraphic line. It can be formed into simple or basic Thuluth, Thuluth Al-Jali, Aynali (the mirrored image style) and the merged Thuluth (Afifi,1992).

According to Nasruddin (2004), Thuluth script was first formulated in the seventh century A.D during the Umayyad caliphate, but it did not develop fully until late ninth century A.D. The author also attests to this point and states that, Thuluth is popular for ornamental inscription. The name means a third perhaps because of the proportion of straight lines to curves, or perhaps because the script was a third, the size of another popular contemporary script. Arguably, it is rarely used for writing the Holy Quran. In his words Thuluth has enjoyed enormous popularity as an ornamental script for calligraphic inscriptions, titles, headings, and colophons. It is still the most important of all the ornamental scripts (Nasruddin, 2004).

The Thuluth style has a special character that make it unique form other Arabic style, is an elegant and cursive script that been used to decorated mosques and Islamic building a long time ago. This style of Arabic calligraphy named Thuluth because it is written by a letter that draws a 
thickness of one third of the diameter of the pen. In addition, because it needs to be written with the letter and thickness of the pen. The Thuluth scritp considred one of the most difficult Arabic fonts in terms of rules and parallels. This script can be characterized by flexibility and robustness of the installation and the ingenuity of authorship. The style of the Thuluth is divided into three types and the srtipt need from the calligrapher a very high skill to make the work looks balanced and harmony from whole structure (Afifi,1990).

Persian style was appeared in Persia in the seventh century. During the 16th century in Persia an extremely important calligraphic development took place with the formulation of Ta'liq scrip. One of the most famous Persian calligraphers was Abd al-Hayy. The calligrapher Abd al-Hayy, from the town of Astarabad, seemed to have played an important role in the script's early development. His patron, Shah Isma'ili, encouraged him to lay down the basic rules for the writing of Ta'liq (Safadi, 1987). Another well-know style of Persian script is named Nistaliq. The Nistaliq script was the predominant style of Persian calligraphy. It was used extensively for copying Persian anthologies, poetry, epics, and other literary works, among them the famous Firdowsi's epic Persian myth Shah Nameh (Book of Kings) but not (seldom) for the Holy Quran. The Persian and Turkish calligraphers continued to use Taliq script as a monumental script for important occasions (Minorsky, Wheeler, 1959).

The Riq'a style is a beautiful line characterized by letters accuracy and extension. It is also characterized by ease and clarity. In deed, the Riq'a style is consider the latest kind of Arabic script was invented by the Turkish calligrapher his name was Mumtaz Beak. The inspiration for this kind of script derived from the Diwani style. This style of writing fomous for every day writing and for advertising and newspaper. The line of Riqa'a is simple, easy to write, read, and not complex. On the other hand, Diwani style invented by the Ottomans and was used for the official line of the Ottoman Empire. The reason for called the line Diwani because is relative to the offices of the government.

The Diwani script has a curved line. Also, the Diwani style is characterized by the flexibility, soft line and easy to use. Calligraphers and artists are tackling Arabic calligraphy from an aesthetic and conceptual angle (Blair, 2006). Arabic calligraphy one of the most beautiful lines that have a special character that is distinguished from the other calligraphy in the world, and it is characterized by elegance, proportion, unity in its characters appear through the movement of the line.

Waterman (2009) states that "Deewani were developed during the Ottoman Empire. This style is probably the most decorative form of Arabic calligraphy. The letters are very close to each other, making it hard to read, in some cases even by those that are fluent in Arabic." Waterman notes that "the style is highly ornamental and decorative.

Geometric principles play an essential role in Arabic calligraphy. As (Khatibi, Sijelmassi) write in The Splendor of Islamic Calligraphy, (1976) the legibility of a text and the beauty of its line require rules of proportion. These rules of proportion are based upon the size of the alif. The first letter of the Arabic alphabet, the alif is a straight, vertical stroke. Besides looking at the alif, calligraphy considers the Arabic dot, which is the unit of measurement in calligraphy (Jafar,2002).

One of the tremendous valued of calligraphic tools was the "Qulam" or reed pen. The Qulam became a valuable trading commodity through the Islamic world. In addition, the Qulam considered one of the old traditional instruments tool use to write in Arabic calligraphy. The tradition calligraphy pen made of natural material such as cane. According to al-Mandis, a geographer from the 10th century, yellowish-yellow bronchial pens were cut off from reeds found in marshes or wetlands. A long time ago the pen was made of a tube of reed cut from both sides. 
The reed pen has a varied in length between 24 and 30 centimetres. Each style of script required a different pen or Qualm and cut at specific angle. For the Ottoman calligraphers the tool was relied on is the Javanese pens, because it is very strong.

In addition, in the Quran the first tool for writing Arabic calligraphy was pen and the importance of using the pen has special quality from Quran. There is a Surah in the Quran called the pen. The "Qualm" is the Arabic word for "pen." The Quran states "Nun. By the pen and what they inscribe." (Surat Al-Qalam-1) In Quran it is clear evidence that relationship between the learning by using the pen as the way to save the words from God.

The Quran was written down in prophet Mohammed's lifetime. Arabic calligraphy has its own tools and mediums that influenced by many cultures such as China and India. The primary tools for calligraphy are the reed or bamboo pens, cutting them in angles way. The second tool is the ink which can be in any colour. Coloured inks were made with the addition of different metal oxides, or arsenic in the case of yellow, while the recipe of Kufi produced dried ink pellets, which were suitable for travel (Derman, 998). But a long time ago the calligraphers used to be using black ink. The mediums have a varity can be applied on vallum, paper, silk, linen, metal, wood, glass, carpet, and ceramic. These mediums were popular for traditional Islamic calligraphy. Writing calligraphy on paper was the most popular kind of written calligraphy, especially verses from the Quarn.

With in the elvated status of calligraphy as a sacerd turust from God, the instruments of written were given a special attention. First, parchment and papyrus were the main materials used for copying the Quran. There are som examples of manuscript of the Quran wrttien on parchment, display durable, lustrous, and luxurious. Later afer few centuries the Chiness introduce paper to Arab in the $9^{\text {th }}$ century. The chiness paper was a turning point because, it was inevitable used for the art of Arabic calligraphy. Through some dramatic changes the essential material for paper was easily shaped and absorbed color better than either parchment or papyrus. Other materials that used for calligraphic decoration are marble, brickwork, glass, textiles, ceramic, woodwork and metal

\subsection{THE IMPORATANCE OF QURANIC COLOR IN CALLIGRAPHY}

In traditional Islamic art and in Arabic calligraphy artists are researching for some colours that been used and ask why these colours have become so much important to Muslims society. Most colours that express Islamic art come from the Quran. The colours in Arabic calligraphy art are symbols and associated with Islamic culture. Some colour like gold and silver have been used throughout the history of Islamic civilizations. In a related study, Khalid (2000) avers that, "Arabic calligraphy is a primary form of art for Islamic visual expression and creativity. Throughout the vast geography of Islamic world, Arabic calligraphy is a symbol representing unity, beauty and power. The aesthetic principles of Arabic calligraphy are reflection of the cultural values of the Muslim world."

The phenomenon of color in the Holy Quran, a manifestation of miracles, artistic and aesthetic expression, and a verbal idiom characterized by the miraculous Qur'anic style, so much so that it was consistent in the text, to perform an important function besides the expressive functions that celebrated the book of God the Wise.

The Quran has references to colours that show the beauty of nature. The word colour is mentioned about nine times in seven verses: Surat An-Nahl- verse 13, Sûrat An-Nahl- verse 69. 
Sûrat Ar-Rûm- verse 22, Sûrat Fâtir -verse 27, Sûrat Fâtir -verse 27, Sûrat Fâtir -verse 28, Sûrat Al-Zumar- verse 21. The most notable verse that mention color is Sûrat Ar-Rûm- verse 22:(God says, And of His signs is that He created for you from yourselves mates that you may find tranquillity in them; and He placed between your affection and mercy.

In deed, in that are signs for a people who give thought. Also, of His signs is the creation of the heavens and the earth and the diversity of your languages and your colours. In deed in that are signs for those of knowledge. Therefore, the Quran mention the diversity of colours and this diversity of colours forms can be seen through most Arabic calligraphy art. According to Jouathan Bloom and Sheila Blair (2011) the variety of meaning associated with colors in Islamic societies suggests that many cultural influences were at work. Although the Quran played an important role local and regional traditions also played their part.

As Arabic culture developed and spread along with Islam, it incorporated and elaborated the folk and scientific knowledge of previous and neighboring civilization. Early Arab scientists largely followed such ancient authors as Aristotle and Ptolemy in seeing three colors red green and blue violet in the rainbow although the colour they identified yellow red and green were not the same (Jouathan, Sheila, 2011). Colours gives an Arabic calligraphy and Islamic art value and harmony because the aspect of unity and variety of colour schemes comes from artists faith and spirit. In general, colour has psychological meaning because of the affect that green, blue, red, yellow, pink black and white have on our feeling. In the Quran there is about seven colours: yellow, white, black green, blue, red, and pink, along with gold and silver, most of these colours can Muslim artists prefer to use when they are creating an artwork.

For example, the colour of yellow is mentioned five times in different meaning sometimes, it refers to happiness and other times it refers to death. The Quran states "It is a yellow cow, bright in its colour, pleasing to the beholders" (Surat Al-Baqarah- verse 69). But the white colour is mentioned about 12 times in 12 verses. An example of use of white colour has a long history assisted with the kiswa. The kiswa means the cover on the kabbab in Mecca. It was made of white linen, then black eventually became. The standard color of the kiswa during the Abbasid caliphate was black. Another colour that mention in the Quran is black repeated seven times. God says, "And eat and drink until the white thread of dawn becomes distinct to you from the black thread [of night]" (Surat Al-Baqarah- verse 187). The Kaaba has a Black Stone and the colour of kiswa is also black.

Another famous colour that is consider as a symbol of Islamic culture is green. The green repeated eight times in the Quran. In deed this colour is considered as a sacred color because it was worn by the prophet Muhammad. In addition to the color that relate to gerrn is blue. Blue is famous in Muslim society and was mentioned just one time in the Quran. But in Muslim country most of the famous mosques are blue for example, Sultan Ahmed Mosque or the Blue Mosque is one of the most famous Islamic structures in the world, located in Istanbul, Turkey. In addition, the use of gold with blue background for the Dome of the Rock in Jerusalem showing the history of the use of this colour with religious buildings.

Red, it is mentioned just one time in the Quran and it presents the colours of mountains. God says "Do you not see that Allah sends down rain from the sky, and We produce thereby fruits of varying colours? And in the mountains are tracts, white and red of varying shades" (Sûrat Fatearverse 27). Another Quranic colour is pink. The pink colour is mentioned just one time like the red colour, when God says, "And when the heaven is split open and becomes rose-coloured" (Surat Ar-Raĥān- verse 37). The color of gold and silver has a long history in Islamic art espically in decoration the Quran with organic decoration and geomatric decoration. God says in the holy Page | 41 
Quran: (Upon the inhabitants will be green garments of fine silk and brocade. And they will be adorned with bracelets of silver, and their Lord will give them a purifying drink. (Surat Al-'Insān 21).

"Those will have gardens of perpetual residence; beneath them rivers will flow. They will be adorned therein with bracelets of gold and will wear green garments of fine silk and brocade, reclining therein on adorned couches. Excellent is the reward, and good is the resting place. (Surat Al-'Insān 21). In Islamic culture green, silver and gold are the colors of paradise. According to Jouathan Bloom and Sheila Blair (2011), the other early examples of the gold scheme are as at Cordoba, associated with religious building. The three great mosques built by Caliph al Walid in Damascus, Jerusalem, and Medina had dedicatory inscriptions now lost but at least in the case of that in Damascus there is the testimony of al masudi writing in the tenth century that it was in the form of golden letters against a blue background.

The golden letters themselves are easily understood and their heritage readily traced (Jouathan, Sheila, 2011). A long time ago the written of the Quran had been used gold with elements of red, blue or green. Calligraphers are choosing colors that has a meaning to explore the traditional Islamic faith and culture throughout their artwork of Arabic calligraphy. God says:( And Allah has brought you out from the wombs of your mothers while you know nothing. And He gave you hearing, sight, and hearts that you might give thanks (to Allah) (Sûrat An-Nahl- verse 78). Through the abbasi dynesty the kufic script was devolped and produce a beautiful abbasi Quran. This Quran was granded with short vertical and exaggerated horizontal line. The words of the abbasi Quran were written in black or gold ink color. The style of kufic script was mainly used in Egypt and Syria during the $10^{\text {th }}$ centuries.

\subsection{CONCLUSION}

Calligraphy developed into sublime art form. The text has been beautifully illuminated throughout the ages in different styles and form after the revelation of the Quran. In deed Arabic calligraphy developed a major art form and it is considered the finest of all kind of Islamic art.

The art of Islamic calligraphy is the art of the beautiful and elegant handwriting in the Islamic world. Throughout the history, Islamic calligraphy has reformed to many styles (Crimsh, 2017). Arabic calligraphy is one of the most sacred kind of art has spiritual dimension. The Arabic language became important after the light of Islam appear and this language has universal spirituality. Calligraphers have been using Arabic calligraphy as a visual language focused on its spiritual and aesthetic aspect.

According to Cultural Considerations: Arabic Calligraphy and Latin Typography, Arabic calligraphy expresses the significance of timelessness with a marked sense of rhythm, and with endless repetitions and decorative patterns. The primary purpose of the pattern is to transform matter so that it loses its solidity and heaviness. The abstract nature of the designs is more significant than the material aspect. Complexity is created to hold the readers attention. Contemplation is encouraged the reader delights in the intricacy. The illusion extends to infinity and the surface is seemingly dissolved. The surface of a page can have a transcendent quality which achieves a desired.

Arabic calligraphy art well-known about its movement, rhythm and dynamism as seen through the calligraphic marks. The aesthetic principles of calligraphy work demonstrate the beauty of Arabic language and culture. Arabic calligraphy started from the seventh and remains in the late twentieth century and this art devoted for secular purposes and associated with Islamic religion. 
In addition, the large geographical background shows many style and calligrapher to do the traditional Islamic art. Each culture has developed their own style and tools of writing Arabic calligraphy. Islamic art has various manifestations that demonstrate simplicity and complexity.

The Arabic calligraphic marks have a repetition, unity, rhythm, balance represent the infinite sense of spirituality behind the calligraphy work. The holy book the "Quran," the word of the prophet Muhammad and the Arabic poems are the source of inspiration to most calligraphers that leading them to creating their form of art based on Islamic heritage. In general, the shape of Arabic calligraphy art is divided into angular and cursive lines a combination of different styles based on tradition Arabic style of writing. The calligraphers must be following Arabic language rules with using conventional tools and some techniques to create their tradition Arabic calligraphy work. Arabic calligraphy art conveys a sense of universal spirituality based on meditation on the meaning behind the words of the Quran and the sacred language.

The numerous scripts of Arabic calligraphy were developed over the Islamic world to serve the Islamic religion, the holy Quran, cultural function and all social life. Islamic calligraphy has a variety, creativity and distinguished form than other scripts. Calligraphers made a massive effort to reach the most shape of beautiful and balance letters of Arabic alnguage. Arabic calligraphy has been using since an ancient time by Arab and Islamic civilization as a form of decoration and ornamentation art in all Islamic places.

The Arabic alphabet is one of the most beautiful characters in the world. It is distinguished by its unique beauty and uniqueness. It has a great cultural material and a variety of schools and professors in different times and places around the Islamic world. The calligraphy of art was interpreted as "spiritual mathematics materialized and developed by application of calligraphic equipment" (Teparic, 2013). Nasr (1987) notes that 'Traditional Islamic art conveys the spirituality and quintessential message of Islam through a timeless language which, precisely because of its timelessness as well as its direct symbolism, is more effective and less problematic than most of the theological explanations of Islam.

\section{List of Reference}

Al-Quran

Afifi, F. S. (1992). “Al-Khat al-Thulth” [Thuluth script]. Egypt: Usamah li al- Nashr wa al Tauzi.

Afifi, F. S. (1990). "Al-Kitabah al-Muta akisab” [The Mirrored Image script]. Egypt: Maktabah Mamduh.

Ali, Wijdan, Suhail Bisharat, Barbican Art Gallery, and Jam ‘'iyah al-Malakiyah lil-Funūn al-Jamilah (Jordan). (1989). Contemporary Art from the Islamic World. London: Scorpion Pub., on behalf of the Royal Society of Fine Arts, Amman.

Blair, Sheila. (2006). Islamic Calligraphy. Edinburgh: Edinburgh University Press.

Brend, Barbara. (1991). Islamic Art. Cambridge, Mass: Harvard University Press.

Bloom, Jonathan, and Sheila Blair. (2011). And Diverse are Their Bues: Color in Islamic Art and Culture. New Haven [Conn.]: Yale University Press.

Blair, S., \& Bloom, J. (2017). By The Pen And What They Write: Writing in Islamic art.

Blankenship, Sherry. (2003) "Cultural Considerations: Arabic Calligraphy and Latin Typography." Design Issues, 19(2), 60-63.

Dutton, Yasin. (2007). Islamic calligraphy. Bulletin of the School of Oriental and African Studies, 70(2), 421-423.

Page $\mid 43$ 
University of London

Derman, M. U. (1998). "Letters in Gold: Ottoman Calligraphy from the Sakep Sabancı Collection, Istanbul." Metropolitan Museum of Art. New York.

David, J. (1989). Calligraphy: The Geometry of the Script in Saudi Aramco World. Sept/Oct, 16-27.

Fu, S., Lowry, G. D., \& Yonemura, A. (1986). "From concept to context”. Freer Gallery of Art, Smithsonian Institution; For sale by the Supt. of Docs., USGPO.

Faruqi, I. \& Lois L. (1986). “The Cultural Atlas of Islam”. American Journal of Islamic Social Sciences, 3(1), 169.

Fayeq, Oweis. (2002). Art as an Educational Tool about the Teaching of Islam. Published by: National Art Education Assosiation. Stable, URL: https://www.jstor.org/stable/3193986.

Ghulam, Yousif Mahmud. (1982). The Art Of Arabic Calligraphy. Lafayette, Ca. (P.O. Box 853, Lafayette 94549): Y.M. Ghulam.

Jafar, M. (2002). “Arabic Calligraphy: Naskh Script for Beginners”. British Museum Press.

Khatibi, Abdelkebir, and Mohamed Sijelmassi. (1996). The Splendor Of Islamic Calligraphy. New York: Thames and Hudson.

Khatibi, A. \& Sijelmassi, M. (1976). "The Splendor Of Islamic Calligraphy”. Thames \& Hudson. London.

Khader, S. (2001). "The Qur'an manuscripts in the al-Haram al-Sharif Islamic Museum, Jerusalem." UK, Journal of Qur'anic Studies, 4(2), 88-90.

Khalid, M (2000). Arabic Calligraphy, 1-6. http://islamicart.com/main/calligraphy/intro.html

Minorsky, V. and Wheeler M. T. (1959). Calligraphers and Painters-A Treatise by Qadi Ahmad, son of Mir-Munshi. (circa AH 1015/AD 1606).Washington.

Nasruddin, S. (2004). an Exbibition of Agfan Calligraphy and Miniature Painting. Dublin, Har Centre Library, 315.

Najda. (1994). “Arabic Calligraphy.” Women Concerned about the Middle East 94707th ser, 1-5.

Nasr, S. H. (1987). Islamic Art and spirituality. New York: State University of New York Pre.

Porter, Venetia, Isabelle Caussé, and British Museum. (2006). Word into Art: Artists of the Modern Middle East. London: British Museum Press.

Razwy, S. A. A. (2014). “A Restatement of the History of Islam and Muslims". Lulu Press, Inc. World Federation of KSI Muslim Communities United Kingdom.

Schimmel, Annemarie. (1990). Calligraphy and Islamic Culture. New York: New York University Press.

Schimmel, A. (1970). "Islamic Calligraphy”. Leiden: E.J. Brill Archive.

Schimmel, A. (1975). "Mystical Dimensions of Islam”. University of North Carolina press.

Sloman, Paul. (2009). Contemporary Art in the Middle East. London: Black Dog.

Siddiqua, S. (2011). Calligraphy - A Significant Islamic Heritage. http://www.imamreza.net/eng/imamrezaphp?accessed on 16th March 2013, 1-2.

Saliu, B. A (2006). Aspects of Kano Cultural Tourism. (ed) in Perspective on Kano Volume I (ed) Uba, A.A and Ado, I.K Volume 1 Telletters Consulting Coy Ltd. , 57-82.

Saliu, A.R (2013). Islamic Art for Peace and Unity: The Nigeria Initiative for National Integration. A paper presented at the opening ceremony of the $2^{\text {nd }}$ Islamic Arts/Calligraphy exhibition, held at conference hall National mosque, Abuja on14th September P.6. 
Safadi, Y. H. (1978). "Islamic Calligraphy”. London: Thames and Hudson.

Teparic, M. (2013). "Figural Representation in the Arabic Calligraphy." Epiphany Journal of Transdisciplinary Studies, 6(2), 145-161. ISSN 1840-3719

Waterman, M. (2009). Itroduction to Arabic Calligraphy. http://www.arabiccalligraphy.com, accessed on $31 / 01 / 2015,6$.

Zoghbi, Pascal. (2011). Graffiti Writer Stone, and Joy Hawley. Arabic graffiti. Berlin, Germany: From Here to Fame Pub.

Zakariya, M. (2002). A Brief Look at the History and Development of Arabic Calligraphy. http://www.zakariya.net/history/index.html. Accessed on 10th, October 2012, 1-6. 